\title{
Description and Identification of Four Species of Plant-parasitic Nematodes Associated with Forage Legumes
}

\author{
Mahfouz M. M. Abd-Elgawad"; Mohamed F.M. Eissa ; Abd-Elmoneim Y. \\ El-Gindi ${ }^{* *}$; Grover C. Smart ${ }^{* * *}$; and Ahmed El-bahrawy ${ }^{* * * *}$. \\ * Plant Pathology Department, National Research Centre. \\ ** Department of Agricultural Zoology and Nematology, Faculty of Agriculture, University of \\ Cairo, Giza, Egypt. \\ *** Department of Entomology and Nematology, IFAS, University of Florida, USA. \\ $* * * *$ Institute for Sustainable Plant Protection, National Council of Research, Bari, Italy.
}

\begin{abstract}
Four species of plant parasitic nematodes were present in soil samples planted with forage legumes at Alachua County, Florida, USA. The detected species Belonolaimus longicaudatus, Criconemella ornate, Hoplolaimus galeatus, and Paratrichodorus minor were described in the present study. They belong to orders Rhabditida (Belonolaimus longicaudatus, Criconemella ornate, and Hoplolaimus galeatus) and Triplonchida (Paratrichodorus minor) and to taxonomical families Dolichodoridae (Belonolaimus longicaudatus), Hoplolaimidae (Hoplolaimus galeatus) Criconematidae (Criconemella ornate), and Trichodoridae (Paratrichodorus minor). The identification of the present specimens was based on the classical taxonomy, following morphological and morphometrical characters in the species specific identification keys.
\end{abstract}

Keywords: Belonolaimus longicaudatus, Criconemella ornate, Hoplolaimus galeatus, Paratrichodorus minor, morphology, species description.

\section{Introduction}

As is widely and rightly held nematodes (round worms) are diversified multicellular animals comprising free living to plant, animal and even humanparasitic species. They represent a group of the most numerous metazoans in soil and aquatic sediments. From an environmental point of view, nematodes are part of nearly all ecosystems in their roles as bacterivores, herbivores, parasites of animals and plants, and consumers of dissolved as well as particulate organic matter (Mekete et al., 2012). Among them, plant-parasitic nematodes (PPNs) form prominent and distinguished group. These latter are mostly hidden enemy of the growers as the nematodes are generally subterranean in habitats and farmers are 
unaware of losses caused by them. A great loss to crops has been reported in quantitative, qualitative and monetary terms. Considering their impact on crops, Abd-Elgawad and Askary (2015) reported an average worldwide crop loss of $12.6 \%$ which equaled $\$ 215.77$ billion due to these nematodes for only the top 20 life-sustaining crops based on the 2010-2013 production figures and prices. Moreover, $14.45 \%$ or $\$ 142.47$ billion was an average annual yield loss in the subsequent group of food or export crops. These figures are staggering, and the authentic figure, when more crops are counted, certainly exceeds such estimations.

Nevertheless, it is noteworthy that PPNs are among the least studied, with close to only 26,000 (estimated < $3 \%$ ) species described to date (Hugot et al., 2001; Mekete et al., 2012). Accuracy of identification is, therefore, fundamental to our understanding and communication of the ecological role of any organism. It goes without saying that PPN identification has its strength in agricultural applications because of its economic participation in nematode management implications. Consequently, PPN species delimitation methods in the context of agricultural and health-related applications are more refined at the species and below species level than methods employed in nematode biodiversity studies. Yet, both groups of studies help in better understanding of nematology and its interaction with relevant disciplines. In fact, specimen identification are imperative not only for choosing adequate management control strategies for PPNs but also for avoiding spreading of such exotic nematodes in quarantine materials. Yet, PPNs are one of the hardest groups to be identified due to their microscopic sizes as well as the difficulties in observing key diagnostic characters/features under conventional light microscope (Carneiro et al., 2017).

On the other hand, legumes represent some of the best quality forages for livestock since they are palatable, help maintain proper functioning of the ruminant digestive processes and stimulate high production of both meat and milk. Since they possess an excellent attribute of biological nitrogen fixation in association with rhizobia, which helps in sustaining soil fertility, legumes are used as green manure by ploughing them into the soil. Considering their impact on crops, PPNs associated with common forage legumes were studied for morphometric identification in this work.

\section{Materials and Methods}

Soil of three experimental areas with established stands of fifteen adapted clover cultivars were sampled for PPNs. The experimental areas, properties of the University of Florida, were located in Alachua County near Gainesville, Florida, USA at altitude of 30 degrees north and a longitude of 82 degrees west. The three experiments, set up initially to test forage cultivars, had been established in a randomized block design with clover cultivars and controls as treatments. The sampled clover cultivars comprised Trifolium repens (white clover) cvs 'FL-XP1', 
'Regal', 'FL-XP2', 'LA-SI', and 'Tillman'; T. pretense (red clover) cv. 'Kenstar'; T. vesiculosum (arrowleaf clover) cvs 'Amclo', 'REPS-5' and 'Yuchi'; T. incarnatum (crimson clover) 'Dixie'; T. subterraneum (subterranean clover) cvs 'Mt. Barker' and 'Woogenellup'; T. alexandrinum (Egyptian clover) cv. 'Bigbee'; Medicago sativa (alfalfa) cv. 'FL-77'; and Melilotus alba var annua (sweet clover) cv. 'Hubam'. Phytonematodes associated with the forage legumes of these experiments were reported to the generic level (Abd-Elgawad et al., 2017). About five 2.5-cm diameter cores were taken randomly within the root zone (upper $15-20 \mathrm{~cm}$ ) from each plot and then mixed thoroughly to form one sample representing the plot. Each sample was placed in a plastic bag, stored in an ice chest, and transported to the nematology laboratory. Samples not processed immediately were stored at $10 \pm 1$ ${ }^{0} \mathrm{C}$ until processed. Nematodes were extracted from $100 \mathrm{~cm}^{3}$ soil from each sample using a centrifugal-flotation technique (Caveness and Jensen, 1955), placed in vials, and stored in a refrigerator at $4^{\circ} \mathrm{C}$ for no more than three days until identified to genera and counted. Thereafter, some of the nematodes extracted from the study (Abd-Elgawad et al., 2017) were taken and processed for identification to the species level as originally described by Goodey (1963). Three percent formalin was used for making temporary mounts of nematodes. One percent water agar was used (for en face mounts) and Zut ${ }^{\circledR}$ slide-ringing compound was used to seal the slides. Drawings were made with the camera lucida technique equipped to the microscope. All measurements except ratios are expressed in $\mu \mathrm{m}$ as means \pm standard deviation. Key references of Rau (1963), Luc and Raski (1981), Jairajpuri and Baqri (1973), and Decraemer (1980) were consulted to identify species of Belonolaimus, Criconernella, Hoplolaimus, and Paratrichodorus. A magnification of $1000 \mathrm{x}$ was used to identify all nematodes. Throughout these identifications, we adopted the systematic scheme of De Ley and Blaxter (2002) for the higher classification which has been updated where appropriate by Decraemer and Hunt (2013) to reflect new taxa proposals.

\section{Results and Discussions}

Species of four genera of plant-parasitic nematodes associated with all the above-mentioned clover cultivars were identified as Belonolaimus longicaudatus, Criconemella ornate, Hoplolaimus galeatus, and Paratrichodorus minor (Tables 1-4; Figs. 1-4). Measurements and drawings of nematode species are presented in Tables 1 through 4 and Figures 1 through 4; respectively. Golden (1971) classified the genera and higher categories of the order Tylenchida in which all of these nematodes are placed except Paratrichodorus minor which is in the order Dorylamida and published by Siddiqi (1973). Nevertheless, family Trichodoridae is no longer part of Dorylaimida and Tylenchida doesn't exist (now it is Rhabditida). In fact, recent molecular phylogenetic analyses recognize 12 clades within the Nematoda, with plant-parasitic taxa located in the basic clade I (Trichodoridae) and clade II (Longidoridae) and in the more advanced clade 12 with the 
Tylenchomorpha (Holterman et al., 2006; Decraemer and Hunt, 2013). Accordingly, the species identified herein belong to orders Rhabditida (Belonolaimus longicaudatus, Criconemella ornate, and Hoplolaimus galeatus) and Triplonchida (Paratrichodorus minor) and to taxonomical families Dolichodoridae (Belonolaimus longicaudatus), Hoplolaimidae (Hoplolaimus galeatus) Criconematidae (Criconemella ornate), and Trichodoridae (Paratrichodorus minor). The morphometric identification carried out herein neither negates the need for molecular tools for its documentation nor declines the presence of other PPN species associated with such forages (Abd-Elgawad et al., 2018). In fact, PPNs have been receiving sufficient attention regarding their taxonomy and evolution and therefore they are currently undergoing continuous modifications in their classification, phylogeny and taxonomy (e.g. Sun et al., 2014; Guesmi-Mzoughi et al., 2016).

Belonolaimus longicaudatus (Table1; Fig.1) was identified using the dichotomous key of Rau (1963). He stated that this species is different from $B$. euthychilus, $B$. gracilis, and $B$. maritimus to which it is related in ratio of stylet length to tail length. Sixty to $100 \%$ of $B$. longicaudatus populations have stylets shorter than tails while the opposite is true with the other species. B. longicaudatus differs from $B$. nortoni in that $B$. longicaudatus has a relatively longer stylet and lips of vulva are not protruding.

Table (1): Measurements and ratios of females and males of Belonolaimus longicaudatus associated with forage legumes.

\begin{tabular}{|c|c|c|c|c|c|c|}
\hline \multirow{3}{*}{$\begin{array}{c}\text { Body regions and } \\
\text { organs }\end{array}$} & \multicolumn{6}{|c|}{ Dimensions $(\mu \mathrm{m})$ and ratios } \\
\hline & \multicolumn{3}{|c|}{ Females $(n=10)$} & \multicolumn{3}{|c|}{ Males $(n=10)$} \\
\hline & Minimum & Maximun & Average $\pm S . D$ & linimur & Maximu & Average \pm S.D. \\
\hline Body length & 2085 & 2871 & $2395 \pm 121$ & 1987 & 2193 & $2031 \pm 136$ \\
\hline Body diameter & 36 & 44 & 41 & 38 & 43 & 41 \\
\hline Tail length & 120 & 172 & $150 \pm 14.8$ & 110 & 169 & $141 \pm 16$ \\
\hline Anal body diameter & 32 & 38 & 34 & 29 & 34 & 31 \\
\hline Stylet length & 118 & 129 & $123 \pm 11.3$ & 112 & 119 & $115 \pm 11$ \\
\hline Esophagus length & 268 & 290 & 276 & 314 & 335 & 325 \\
\hline Distance from head to vulva & 1028 & 1520 & 1278 & -- & - & - \\
\hline Spicule length & - & - & - & 39 & 47 & 43 \\
\hline A ratio & 62 & 67 & - & 61 & 65 & - \\
\hline$B$ ratio & 7.8 & 8.3 & - & 6.6 & 7.3 & - \\
\hline $\mathrm{C}$ ratio & 14 & 19 & - & 13 & 15 & - \\
\hline Ć ratio & 3.8 & 4.5 & - & 3.8 & 3.9 & - \\
\hline V\% & $49 \%$ & $55 \%$ & - & - & - & - \\
\hline
\end{tabular}




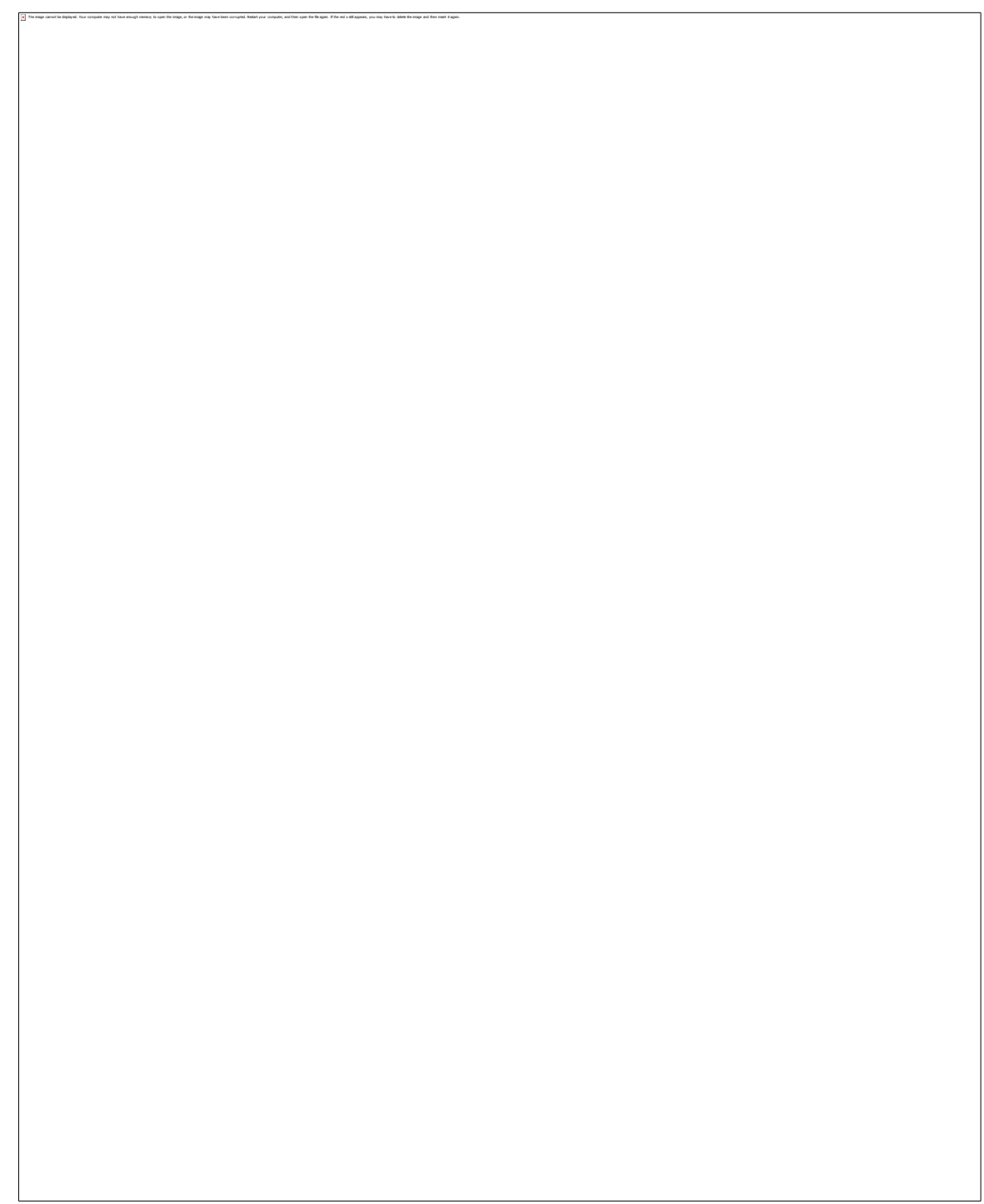

Fig. (1): Belonolaimus longicaudatus (Rau, 1958).

(A) Anterior body region, (B) Head region, (C) Vulval region, (D) Female tail, E - Male tail.

Criconemella ornate (Table 2; Fig. 2) is related to C. curvatum but differs from the latter by the absence of labial plates and by the pointed outline of the anterior vulvar flap (Raski, 1952). Additional important features of $C$. ornate is the presence of the sub-lateral lobes and the relatively few annules, i.e., 87 to 92 annules (Raski, 1958). 
Table (2): Measurements and ratios of females of Criconemella ornate associated with forage legumes.

\begin{tabular}{lccc}
\hline \multirow{2}{*}{ Body regions and organs } & \multicolumn{2}{c}{ Dimensions $(\boldsymbol{\mu m})$ and ratios $(\mathbf{n}=\mathbf{1 3})$} \\
\cline { 2 - 4 } & Minimum & Maximum & Average \pm S.D. \\
\hline Body length & 340 & 460 & $404 \pm 34$ \\
Body diameter & 28 & 46 & 37 \\
Tail length & 14 & 27 & $21 \pm 5.4$ \\
Anal body diameter & 13 & 24 & 19 \\
Stylet length & 44 & 61 & $52 \pm 4.5$ \\
Esophagus length & 85 & 127 & 103 \\
Distance from head to vulva & 310 & 395 & 366 \\
Spicule length & - & -- & -- \\
A ratio & 9 & 16 & -- \\
B ratio & 3 & 4 & -- \\
C ratio & 16 & 27 & - \\
Ć ratio & 1.1 & 1.1 & - \\
V\% & $86 \%$ & $96 \%$ & $91 \%$ \\
\hline
\end{tabular}

Jairajpuri and Baqri (1973) presented a key for Hoplolaimus spp. They differentiated between $H$. Tylenchiformis, having three annules in the lip region and female tails usually bluntly rounded, and $H$. galeatus (Table 3; Fig. 3 ), having four or more annules and female tails rounded. Also, they used the following characteristics of $H$. galeatus to differentiate it from other Hoplolaimus spp.: four incisures on the body, excretory pore located below the hemizonid, one phasmid in anterior part of the body and one phasmid in the posterior part of it, and spicules $40-50 \mu \mathrm{m}$ long.

Table (3): Measurements and ratios of females and males of Hoplolaimus galeatus associated with forage legumes.

\begin{tabular}{|c|c|c|c|c|c|c|}
\hline \multirow{3}{*}{ Body regions and organs } & \multicolumn{6}{|c|}{ Dimensions $(\mu \mathrm{m})$ and ratios } \\
\hline & \multicolumn{3}{|c|}{ Females $(n=10)$} & \multicolumn{3}{|c|}{ Males $(n=4)$} \\
\hline & Minimum & Maximum & $\begin{array}{c}\text { Average } \pm \\
\text { S.D. }\end{array}$ & Minimum & Maximum & $\begin{array}{c}\text { Average } \pm \\
\text { S.D. }\end{array}$ \\
\hline Body length & 1283 & 1643 & $1464 \pm 119$ & 983 & 1195 & $1072 \pm 99$ \\
\hline Body diameter & 40 & 55 & 47 & 35 & 42 & 39 \\
\hline Tail length & 15 & 37 & $26 \pm 8$ & 20 & 32 & $26 \pm 5$ \\
\hline Anal body diameter & 31 & 39 & 35 & 25 & 33 & 28 \\
\hline Stylet length & 48 & 60 & $5.2 \pm 4.6$ & 42 & 50 & $45 \pm 3.6$ \\
\hline Esophagus length & 178 & 220 & 200 & 165 & 190 & 180 \\
\hline Distance from head to vulva & 736 & 853 & 807 & -- & -- & -- \\
\hline Spicule length & -- & -- & -- & 51 & 59 & 55 \\
\hline A ratio & 25.8 & 37.8 & -- & 28.1 & 28.5 & -- \\
\hline B ratio & 6.7 & 8.4 & -- & 6 & 6.3 & -- \\
\hline C ratio & 38.4 & 97.6 & -- & 37.3 & 49.2 & -- \\
\hline Ć ratio & 0.5 & 1.0 & -- & 0.8 & 1.0 & -- \\
\hline V\% & $52 \%$ & $58 \%$ & -- & -- & -- & -- \\
\hline
\end{tabular}




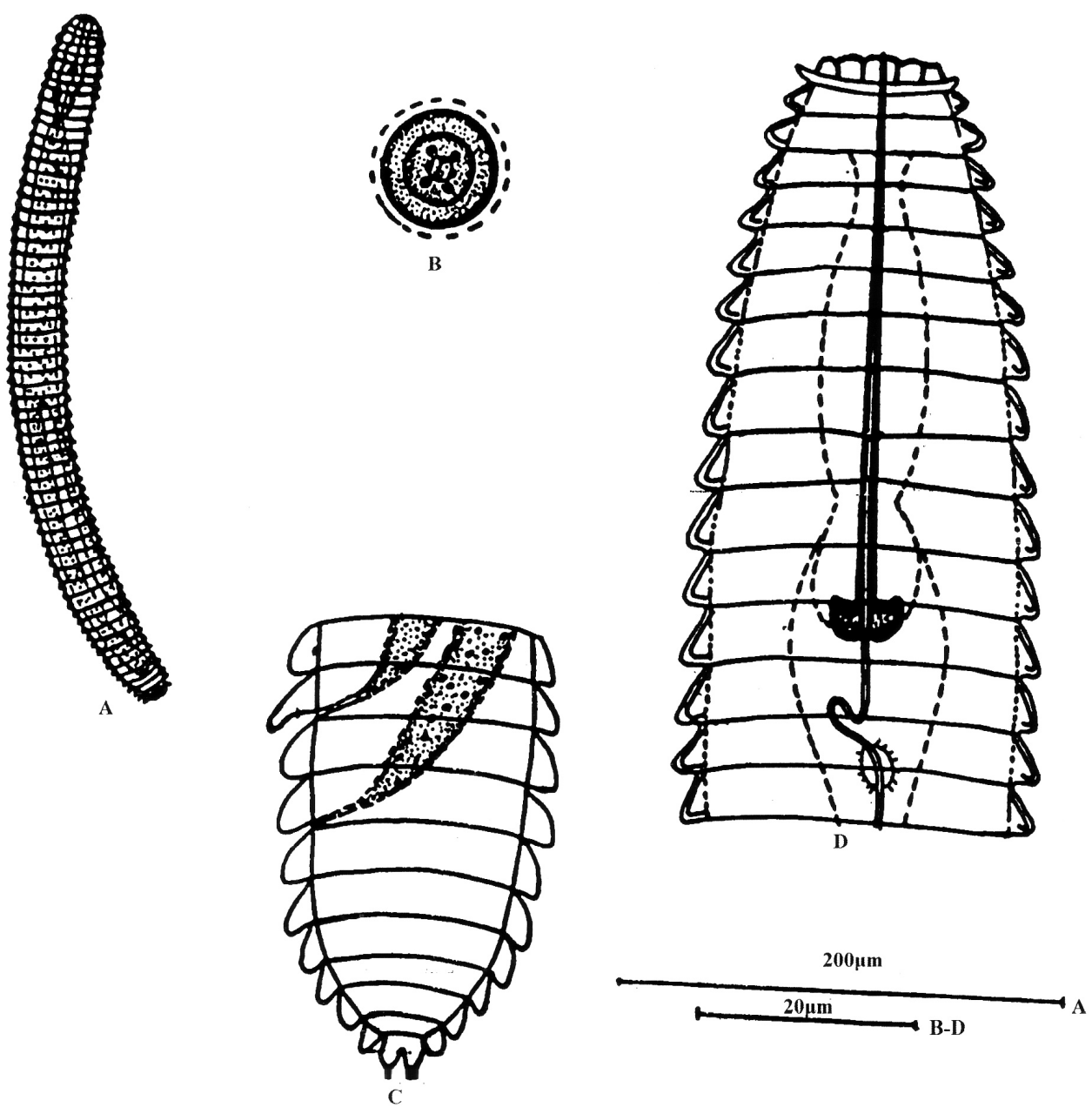

Fig. (2): Criconemella ornate (Raaki, 1958, Luc \& Raski, 1981).

(A) Adult female, (B) Head en face view, (C) Female tail, (D) Anterior body region. 

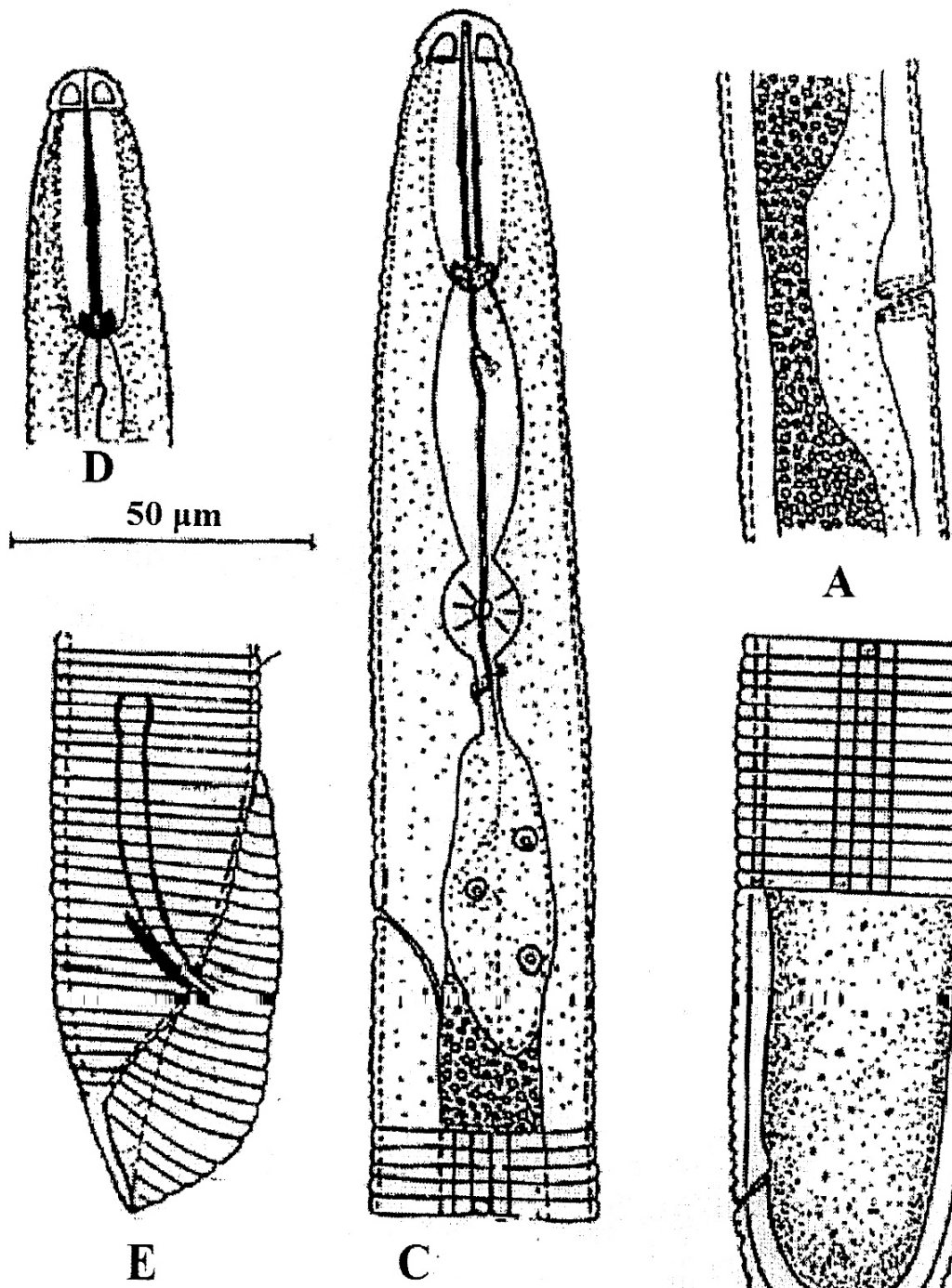

E

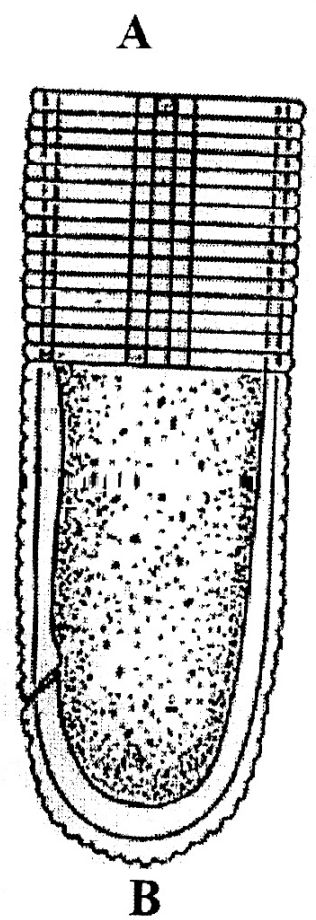

Fig. (3): Hoplolabnus galeatus (Cobb, 1913, Thorne, 1935).

(A) Vulval region, (B) Female tail, (C) Anterior body region, (D) Male, head region, (E) Male, tail region. 
After Siddiqi's division (1973) of the genus Trichodorus into Paratrichodorus and Trichodorus, $_{2}$ there had been considerable confusion in the literature because some authors apparently had not recognized Paratrichodorus spp. as a valid genus, whereas others had (Perry and Rhoades, 1982). Now, both genera are well established (e.g., Decraemer and Hunt, 2013). In our specimens (Table 4; Fig. 4) the two characters used for separating the genus, i.e. male with bursa and female with weak and indistinct sclerotization between the vulva and vagina were recognizable and it keys to $P$. christiei. Yet, our specimens agreed with the synonomy of $P$. christiei and $P$. minor since the lengths of the onchiostyle and spicules of our specimens overlap those of both species (Loof, 1975; Decraemer, 1980).

Table (4): Measurements and ratios of females and males of Paratrichodorus minor associated with forage legumes.

\begin{tabular}{|c|c|c|c|c|c|c|}
\hline \multirow{3}{*}{ Body regions and organs } & \multicolumn{6}{|c|}{ Dimensions $(\mu \mathrm{m})$ and ratios } \\
\hline & \multicolumn{3}{|c|}{ Females $(n=10)$} & \multicolumn{3}{|c|}{ Males $(n=4)$} \\
\hline & Minimum & Maximum & $\begin{array}{l}\text { Average } \pm \\
\text { S.D. }\end{array}$ & Minimum & Maximum & $\begin{array}{c}\text { Average } \pm \\
\text { S.D. }\end{array}$ \\
\hline Body length & 462 & 735 & $610 \pm 117$ & 589 & 692 & $633 \pm 4$ \\
\hline Body diameter & 30 & 49 & 35 & 34 & 38 & 37 \\
\hline Tail length & -- & -- & -- & 19 & 23 & $20 \pm 2$ \\
\hline Anal body diameter & -- & -- & -- & 9 & 12 & 10 \\
\hline Stylet length & 30 & 48 & $41 \pm 8$ & 32 & 40 & $36 \pm 4$ \\
\hline Esophagus length & 96 & 122 & 106 & 85 & 90 & 87 \\
\hline Distance from head to vulva & 240 & 370 & 310 & -- & -- & -- \\
\hline Spicule length & -- & -- & -- & 58 & 66 & 61 \\
\hline A ratio & 15 & 15.4 & 15.2 & 17.3 & 18.2 & -- \\
\hline$B$ ratio & 4.8 & 6 & 5.4 & 6.9 & 7.7 & -- \\
\hline C ratio & -- & -- & -- & 30 & 31 & -- \\
\hline Ć ratio & -- & -- & -- & 1.9 & 2.1 & -- \\
\hline V\% & $50 \%$ & $52 \%$ & $51 \%$ & -- & -- & $=$ \\
\hline
\end{tabular}



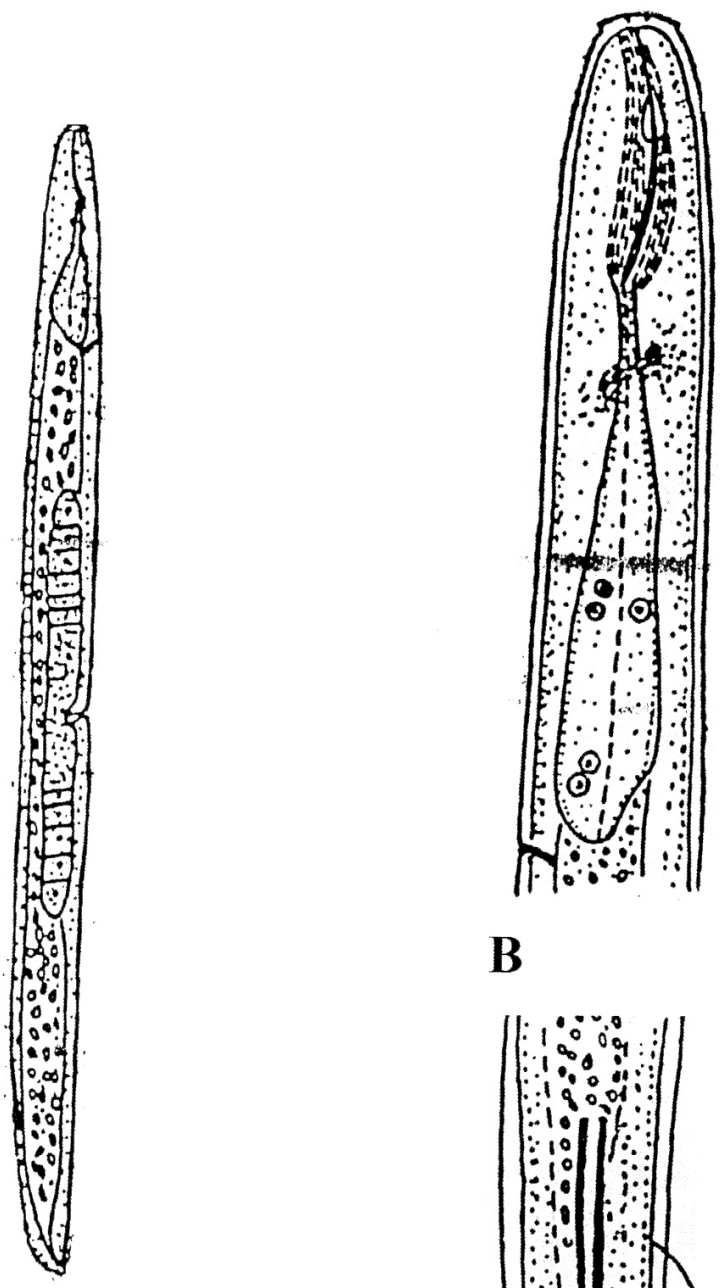

B
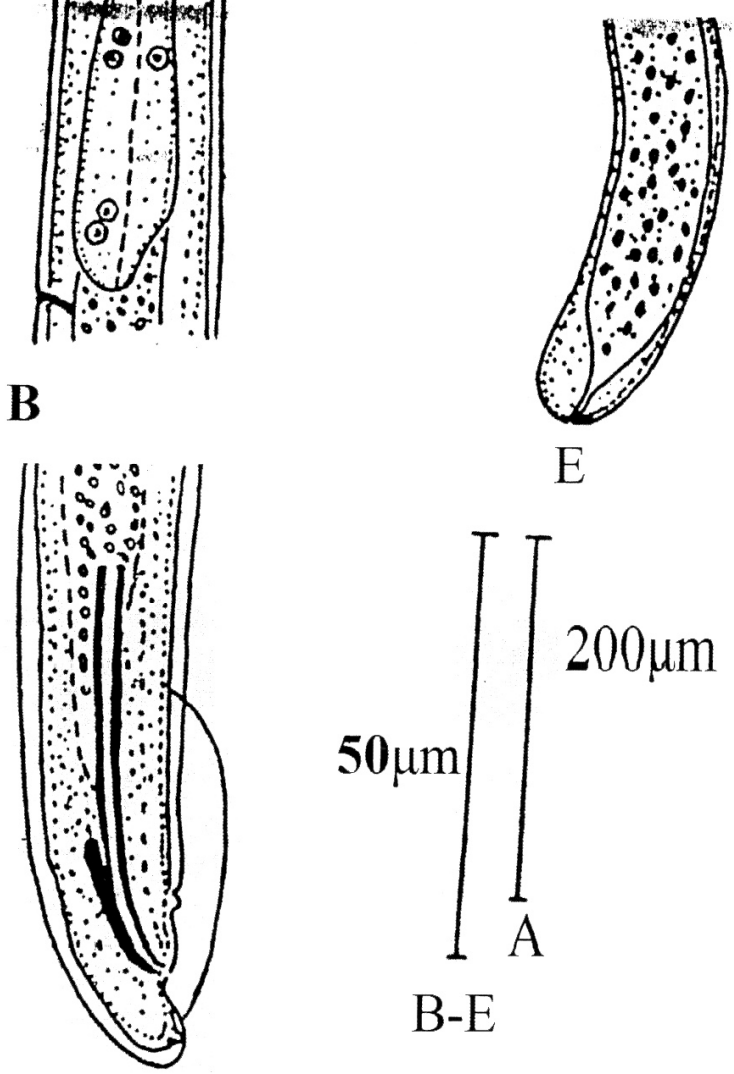

E

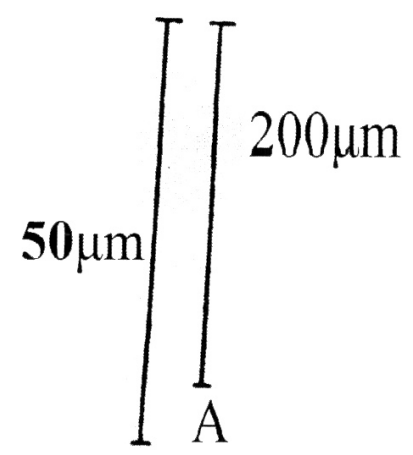

B-E

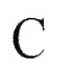

Fig. (4) Paratrichodorus minor (Allen,1957, Siddiqi, 1973).

(A) Adult female, (B) Female, anterior body region, (C) Male tail, (D) Vulval region, E- Female tail. 


\section{Acknowledgement}

This study was supported in part by the NRC In-house project entitled 'Pesticide alternatives against soilborne pathogens attacking legume cultivation in Egypt'.

\section{References}

Abd-Elgawad M.M.M., Askary T.H. (2015). Impact of phytonematodes on agriculture economy. In: Biocontrol Agents of Phytonematodes. Askary, T.H., and Martinelli, P.R.P. (eds), pp. 3-49. CAB International, Wallingford, UK.

Abd-Elgawad, M.M.M., Eissa, M.F.M., El-Gindi A.Y., and Smart, G.C. (2017) Plant-parasitic nematodes associated with forage legumes planted in fallow and into living grass sod. Egyptian Journal of Agronematology 16(1): 39-49.

Abd-Elgawad, M.M.M., Eissa, M.F.M., El-Gindi A.Y., Smart, G.C. and Elbahrawy, A. (2018). Identification of five phytonematode species associated with forage legumes. Egyptian Journal of Agronematology 17(1): In press.

Carneiro, R.M.D.G., Silva, F.S.O., Correia, V.R. (2017). Methods and tools currently used for the identification of plant parasitic nematodes. In: Nematology- Concepts, diagnosis and control. Shah, M.M. and Mahamood, M.(eds), pp. 19-35, Rijeka, Croatia, InTech Open, DOI: 10.5772/66851.

Caveness, F.E and Jensen, H.J. (1955). Modification of the centrifugal-flotation technique for the isolation and concentration of nematodes and their eggs in soil. Proceedings of the Helminthological Society of Washington 22: 8789.

De Ley, P. and Blaxter, M.L. (2002). 1. Systematic position and phylogeny. In: Biology of Nematodes. Lee, D. (Ed.), pp. 1-30. The Harwood Academic Publishers, Reading, UK.

Decraemer, W. (1980). Systematics of the Trichodoridae (Nematoda) with keys to their species. Revue De Nematologie 3(1): 81-99.

Decraemer, W. and Hunt, D.J. (2013). Structure and classification. In: Plant Nematology, 2nd edn. Perry, R.N. and Moens, M. (eds), pp. 3-39. CAB International, Wallingford, UK.

Golden, A. M. (1971). Classification of the genus and higher categories of the order Tylenchida (Nematoda). In: Plant parasitic nematodes. Vol. 1. Zuckerman, B. M., Mai, W. F. and R. A. Rohde (eds), pp. 191-232. Academic Press, New York. 
Goodey, J.B. (1963). Laboratory methods for work with plant and soil nematodes. Ministry Agric., Fish. and Food. Tech. Bull. No. 2, London, 72 pp.

Guesmi-Mzoughi, Archidona-Yuste, A., Cantalapiedra-Navarrete, C., Regaieg, H., Horrigue-Raouani, N., Palomares-RIUS, J.E. and Castillo, P. (2016). First report of the spiral nematode Rotylenchus incultus (Nematoda: Hoplolaimidae) from cultivated olive in Tunisia, with additional molecular data on Rotylenchus eximius. Journal of Nematology 48(3):136-138.

Holterman, M., van der Wurff, A., van den Elsen. S., van Megen, H., Bongers, T., Holovachov, O., Bakker, J. and Helder, J. (2006). Phylum-wide analysis of SSU rDNA reveals deep phylogenetic relationships among nematodes and accelerated evolution toward crown clades. Molecular Biology and Evolution 23:1792-1800.

Hugot, J., P. Baujard, and S. Morand (2001). Biodiversity in helminths and nematodes as a field study: an overview. Nematology 3: 199-208.

Jairajpuri, M.S. and Baqri, Q.H. (1973). Nematodes of high altitude in India. I. Four new species of Tylenchida.Nematologica 19: 19-30.

Loof, P.A.A. (1975). Taxonomy of Trichodoridae. In: Nematode Vectors of Plant Viruses. Lamberti, F., Taylor, C.E., and Seinhorst, J.W. (eds), pp. 103-127. New York, Plenum Press.

Luc, M. and Raski, D.J. (1981). Status of the genera Macroposthonia, Criconemoides, Criconemella and Xenocriconemella (Criconematidae : Nematoda). Revue De Nematologie 4 (1): 3-21.

Mekete T., Dababat A., Sekora N., Akyazi F., Abebe E. (2012). Identification key for agriculturally important plant-parasitic nematodes Prepared for the International Nematode Diagnosis and Identification Course 2012 - A manual for nematology. Mexico, D.F.: CIMMYT.

Perry, V.G. and Rhoades, H.L. (1982). The trichodorid nematodes. In: Nematology in the Southern Region of the United States 276. Riggs, R.D. (ed.), pp. 183187. Southern Cooperative series Bulletin, Fayetteville, Arkansas, USA.

Raski, D.J. (1952). On the morphology of Criconemoides Taylor, 1936, with descriptions of six new species (Nematoda: Criconematidae). Proc. Helminth. Soc. Wash. 19: 85-99.

Raski, D.J. (1958). Nomenclatorial notes on the genus Criconemoides: Criconematidae) with a key to the species. Proc. Helminth. Soc. Wash. 25: 139-142.

Rau, G. J. (1963). Three new species of Belonolaimus (Nematoda: Tylenchida) with additional data on $B$. longicaudatus and $B$. gracilis. Proceedings of the Helminthological Society of Washington 30:119-128. 
Siddiqi, M.R. (1973). Systematics of the genus Trichodorus Cobb, 1913 (Nematoda: Dorylaimida), with descriptions of three new species. Nematologica 19: 259-278.

Sun L., Zhuo K., Lin B., Wang H., Liao J. (2014). The Complete Mitochondrial Genome of Meloidogyne graminicola (Tylenchina): A Unique Gene Arrangement and Its Phylogenetic Implications. PLoS ONE 9(6): e98558. doi:10.1371/journal.pone.0098558 


\section{وصف وتعريف أربعة أنواع من النيماتودا المتطفلة نباتيًا المرتبطة بالبقوليات العلفية}

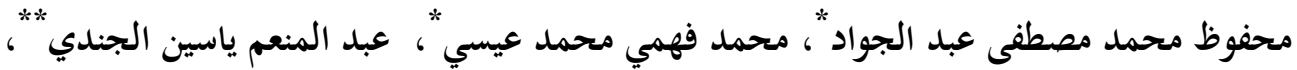

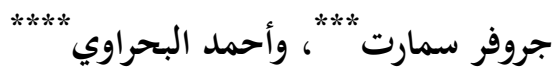

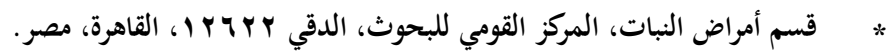

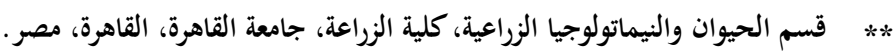

*** * ق *سم الحشرات والنيماتولوجي، معهد علوم الغذاء والزراعة، جامعة فلوريدا، الولايات المتحدة الأمريكية.

***** معهد الوقاية المستدامة للنبات، المجلس القومي للبحوث، مدينة باري، إيطاليا.

\section{الملخص العربي}

تم وصف وتعريف أربعة أنواع من النيماتودا المتطفلة نباتيا المرتبطة بالبقوليات العلفية في مقاطعة

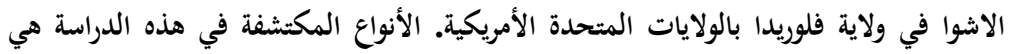

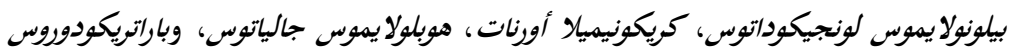

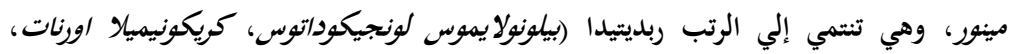

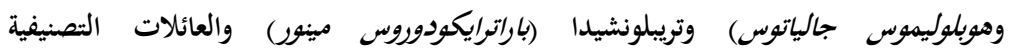

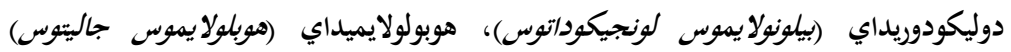

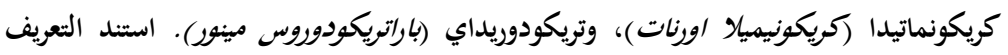

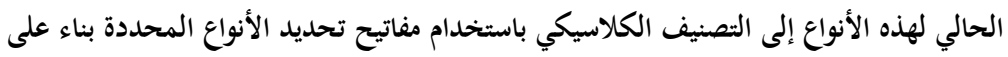
الصفات والقياسات المورفولوجية (الخاصة بالشكل الظاهري).

الكلمات الدالة: بيلونولايموس لونجيكوداتوس - كريكونيميلا اورنات - هوبلولا يموس جالياتوس باراتويكودوروس مينور - الشكل الظاهري - وصف الأنواع. 